\title{
White Matter of the Spinal Cord
}

National Cancer Institute

\section{Source}

National Cancer Institute. White Matter of the Spinal Cord. NCI Thesaurus. Code C33893.

The superficial nerve tissue of the spinal cord. It is composed of nerve cell processes, i.e. extensions (axons), which connect various grey matter areas of the spinal cord to each other and carry nerve impulses to and from the nerve cell bodies within the central nervous system (neurons). Spinal white matter does not contain dendrites. White matter is disting uished in that it is composed of axonal nerve fibers covered by a myelin sheath. 